\title{
ЛАТИНСЬКА АМЕРИКА
}

УДК 94:327(73 + 729,1)"18/19"

http://doi.org/10.17721/2521-1706.2016.02.191-197

Катерина Касаткіна, аспірантка,

Запорізький національний університет

\section{МІСЦЕ КУБИ СЕРЕД ЗОВНІШНЬОПОЛІТИЧНИХ ІНТЕРЕСІВ США (ХІХ - СЕРЕДИНА ХХ ст.)}

\begin{abstract}
Анотація. $У$ статті здійснена спроба визначити місие Куби серед зовнішньополітичних інтересів США у XIX-середині XX cm. 3 ичією метою виокремленні пріоритетні напрямки зовнішньої політики Сполучених Штатів означеного періоду та подана ̈̈х загальна характеристика. Особливу увагу приділено місию латиноамериканського регіону в системі американських національних інтересів. Проведено аналіз факторів, щуо вплинули на формування політики США щуодо Куби $і$ визначили характер ї̈ якісних змін упродовж означеного періоду. В результаті проведеного дослідження автор дійшов висновку, щуо політика Сполучених Штатів щчодо Куби і місие, яке вона займала серед зовнішньополітичних пріоритетів Вашингтону у ХІХ - середині XX cm., зазнали певних змін. Якщзо у XIX cm., в процесі становлення американської державності, Куба розглядалася як потенційна складова самих Сполучених Штатів Америки, то вже на початку XX cm., відмовивиись від включення острова до свого складу, США отримали практично повний контроль над його внутрішньою та зовнішньою політикою. При иьому Куба стала розглядатися у загальному контексті їх латиноамериканської політики. Після перемоги революиії 1959 р. і початку радянськокубинського співробітництва, Куба стала розглядатися США через призму протистояння з Радянським Союзом в рамках Холодної війни і тому знову зайняла одне $з$ ключових місиь серед американських національних інтересів.
\end{abstract}

Ключові слова: США, Куба, Латинська Америка, політика великого кийка, доларова дипломатія.

Вивчення зовнішньої політики США щодо Куби завжди привертало i привертає увагу дослідників. Актуальність даної проблематики багато у чому обумовлена винятковим характером американсько-кубинських відносин, які протягом більш ніж двохсот років неодноразово трансформувалися, демонструючи різні форми взаємодії від практично повного американського домінування до конфронтаційного протистояння й економічної блокади острова. Чергові зміни у зовнішньополітичному курсі США щодо Куби були пов'язані 3 відновленням у 2015 р. дипломатичних відносин між Вашингтоном і Гаваною, розірваними понад півстоліття тому, та визнанням неефективності політики, що проводилася Білим домом. Незважаючи на певну долю скептицизму, нормалізація американськокубинських відносин сприймається світовою громадськістю як повернення до їх природного стану. Однак, слід визнати, що для кращого розуміння процесів вироблення нової форми взаємодії необхідно звернутися до дослідження історичних особливостей формування зовнішньополітичного курсу США щодо Куби у XIX - середині XX ст. і визначити, яке положення займала ця острівна держава у системі американських національних пріоритетів. 
Актуальність дослідження кубинського напрямку зовнішньої політики Сполучених Штатів у нашій країні і за кордоном підтверджується чималою кількістю робіт, що вийшло за цією тематикою. Багато з них присвячені загальним питанням американо-кубинських відносин у XIX - середині XX ст. Більшу частину таких досліджень складають роботи зарубіжних істориків, таких як Е. Моралес Домінгес [11], Л. Перес [12], Дж. Франклін [6]. Окрему групу досліджень складають роботи, що стосуються вивчення певних питань кубинської політики Вашингтона. Серед них хотілося б відзначити публікації У. ЛеоГранда і П. Корнблаха [8], Н. Пасічник [1], О. Скляренко [2], Є. Тусінова [3], Н. Уайта [18].

Незважаючи на наявність досить значної кількості публікацій, присвячених політиці США щодо Куби, робіт, в яких був би проведений узагальнюючий аналіз положення, яке займала Куба в американській зовнішній політиці, вкрай мало. Мета дослідження в рамках даної публікації полягає у спробі визначити місце Куби серед зовнішньополітичних інтересів США у XIX - середині XX ст. Вивчення якісних змін кубинської політики Вашингтону у зазначений хронологічний період дозволить простежити еволюцію ролі Куби у системі американських національних пріоритетів.

Формування зовнішньої політики США і її кубинського напрямку проходило у тісному зв'язку із становленням американської державності. Ще в часи, коли вона була іспанською колонією, Куба привертала увагу батьків-засновників географічною близькістю i військово-стратегічною перевагою. Як відзначав американський історик А. Шлезінгер, США розглядали острів як природне доповнення до американської системи і планували його приєднання при першій ж нагоді. Це було викликано необхідністю підтримати цілісність самих Сполучених Штатів [14, с. 44]. У своєму прагненні створити імперію, подібну Риму, i розширити американську територію на південь, Вашингтон протягом усього XIX ст. неодноразово робив спроби викупити Кубу у Іспанії або анексувати іiі. Так, у 1808 р. Т. Джефферсон 3 цією метою відправив на острів генерала Дж. Уїлкінсона. Однак, Іспанія не була у цьому зацікавлена. Питання про анексію піднімалося держсекретарем США Дж. К. Адамсом у 1823 р. i, доповнене ідеями Manifest Destiny про особливу місію Сполучених Штатів, не втрачало своєї актуальності до кінця століття [6, с. 2-4]. Формування логічно вивіреного i теоретично обгрунтованого зовнішньополітичного курсу США щодо Куби було підкріплено ідеями доктрини Монро, озвученими президентом Дж. Монро у щорічному посланні Конгресу 2 грудня 1823 р. [10]. Як відомо, Вашингтон прагнув обмежити присутність європейських держав не тільки на острові, а й у Західній півкулі в цілому. Таким чином, політико-філософські ідеї першої половини XIX ст. стали основою для побудови американської зовнішньополітичної стратегії щодо Куби як найбільш вірогідною складової частини самих Сполучених Штатів Америки.

Втручання США у війну за незалежність Куби 1895-1898 рр. і наступні події іспано-американської війни 1898 р. поклали край колоніальній Іспанській імперії у Карибському басейні і на Тихому океані. Безпосередньо перед оголошенням війни, 19 квітня 1898 р. Конгрес США прийняв резолюцію, що визнала незалежність Куби і вимагала негайного виведення іспанських військ з острову [15, с. 738-739]. Крім того, у поправці сенатора Г. М. Теллера, включеній до резолюції, прописувалася відмова Сполучених Штатів від наміру анексувати острів і передати владу народу 
Куби, як тільки буде встановлено мир. На наступний день президент У. Мак-Кінлі підписав резолюцію. Ї̈̈ прийняття було обумовлено настроями американської громадськості, яка співчувала борцям за незалежність, i прагненням США заручитися підтримкою кубинського народу у війні 3 Іспанією. Таким чином, Вашингтон був змушений відмовитися від прямої анексії Куби, зосередивши зусилля на пошуках нових форм американсько-кубинської взаємодії.

Після закінчення війни, за умовами Паризького мирного договору від 10 грудня 1898 р. [17], США отримали контроль над колишніми іспанськими колоніями в Пуерто-Ріко, на Філіппінах, Гуамі, а також над процесом становлення державної незалежності на Кубі. На острів були введені американські війська. Територіальні надбання і успіхи в дипломатичній сфері знаменували початок гегемонії Сполучених Штатів у Західній півкулі $\mathrm{i}$ сприяли розширенню американської присутності у всіх частинах світу. Куба, яка опинилася у межах американського впливу, зайняла одне з центральних місць в латиноамериканській політиці США поряд з Мексикою, з Пуерто-Ріко, Гуамом і Філіппінами.

На початку XX ст. Сполучені Штати продовжили зміцнювати свої позиції на Кубі. На зміну поправці Теллера прийшла поправка сенатора О. Х. Платта, як доповнення до законопроекту про асигнування армії США від 2 березня 1901 р. [9, c. 897-898]. Поправка містила умови, за яких Сполучені Штати припиняють військову окупацію Куби, але залишала за ними право втручатися у внутрішню i зовнішню політику острова. Її основні положення були інтегровані до кубинської конституції 1901 р. та 20 травня 1902 р. Куба змогла заявити про свою незалежність. У 1903 р. Вашингтон, який продовжував зміцнювати свої позиції на острові, уклав з новим кубинським урядом угоду, за умовами якої, Куба надавала США в оренду території під військово-морські бази [4], що остаточно перетворило острів на стратегічно важливий об'єкт для американської системи національної безпеки.

Варто відзначити, що політика США стосовно Куби у перші десятиліття XX ст. відображала загальні риси ії пріоритетного латиноамериканського напрямку i розвивалася у руслі політики «Великого кийка» Т. Рузвельта та «Доларової дипломатії» В. Тафта. Перша зводилася до проголошення превентивного втручання США у внутрішні справи латиноамериканських держав i до одностороннього прийняття на себе функцій міжнародної поліцейської сили. Починаючи 3 іспаноамериканської війни 1898 р. Сполучені Штати провели серію військових акцій у Центральній Америці і Карибському басейні, встановивши свій протекторат над Панамою, Гондурасом, Нікарагуа, Мексикою, Гаїті і Домініканською Республікою. У нерозривному зв'язку із політикою «Великого кийка» розвивалася і «Доларова дипломатія» В. Тафта. Вона відображала потреби американської економіки, що зростала, і передбачала створення найбільш сприятливих умов для американського капіталу за кордоном [7, с. 807-808]. Так, для захисту своїх національних інтересів Вашингтон неодноразово організовував військові вторгнення на Кубу: у 19061909 рр., 1912 р. та 1917-1922 pp.

Складна економічна ситуація всередині країни наприкінці 1920-х рр. зробила позицію Сполучених Штатів уразливою у Латинській Америці і ускладнила наступальну політику в регіоні. Це призвело до відмови від експансії сили і спричинило проголошення політики «Добросусідства» Ф. Д. Рузвельта. Її основні принципи були озвучені американським президентом у його інавгураційній 
промові 4 березня 1933 р. [13]. Практична реалізація політики «Добросусідства» передбачала невтручання Сполучених Штатів у внутрішню політику країн Латинської Америки i створення сприятливих умов для взаємовигідних торгівельних відносин. Вплив нового політичного курсу Ф. Д. Рузвельта на американсько-кубинські відносини відбився у скасуванні у 1934 р. поправки Платта і розірванні угоди 1903 р. Натомість, у тому ж році, була укладена нова угода, у якій низка принизливих для кубинців положень попереднього договору була виключена, але орендовані США території залишилися за ними [16]. У той же час, внутрішньополітична ситуація на Кубі у 1930-ті - 1940-ві рр. сприяла тісній співпраці Вашингтона і Гавани. Вона полягала у наданні економічної та військової допомоги кубинському лідеру Ф. Батисті і призвела до практично повного панування Сполучених Штатів над економікою острову.

Під час Другої світової війни була закріплена позитивна тенденція у взаємовідносинах США з Латинською Америкою. Вона була обумовлена участю латиноамериканських країн у війні на боці антигітлерівської коаліції і підтримкою зусиль Вашингтону в Європі та Азії. Крім того, самі держави регіону стали проявляти зацікавленість у нових формах взаємин із північним сусідом, але продовжували залишатися залежними від нього у своєму політичному та економічному житті. Однак, війна внесла зміни до основних напрямів зовнішньої політики Сполучених Штатів. 3 іiі закінченням було покладено край американському ізоляціонізму і намічений перехід США від позицій пасивного спостерігача до одного з лідерів світової політики. У зв'язку з цим, європейський напрям став більш пріоритетним ніж латиноамериканський. Саме тому увага до Куби, яка залишалася стабільно залежною державою, слабшає.

Початок Холодної війни призвів до дестабілізації проамериканських режимів у Латинській Америці та поклав край політиці «Добросусідства». 3 метою запобігання приходу до влади прокомуністичних урядів у регіоні, відновилася практика інтервенціоналізму. Крім того, у 1948 р. на базі Панамериканського союзу була створена Організація американських держав, яка представляла собою систему колективної безпеки у Західній півкулі. Незважаючи на незалежний статус цієї організації, США, які використовували засоби економічного і політичного тиску, неодноразово нав'язували ОАД вигідні для себе рішення. Так, під тиском Вашингтону, на Х Міжамериканській конференції у Каракасі (Венесуела) у березні 1954 р. була прийнята так звана «Антикомуністична резолюція», яка узаконювала колективне втручання у внутрішні справи латиноамериканських держав під приводом боротьби 3 міжнародним комуністичним рухом [5]. Проте, якщо оцінювати політику США у Латинській Америці у першому десятилітті Холодної війни з точки зору пріоритетності їх зовнішньополітичного курсу, то слід зазначити зміщення фокусу політичних інтересів 3 латиноамериканського регіону на європейський, близькосхідний і східно-азійський. Отже, у цей період інтерес до американсько-кубинських відносин у контексті латиноамериканської політики США продовжував залишатися стабільно невисоким.

Превентивні заходи, що вживалися Сполученими Штатами у Західній півкулі, не запобігли революції 1959 р. на Кубі. Незважаючи на підтримку ними проамериканського режиму Ф. Батисти, до влади прийшов молодий кубинський революціонер Ф. Кастро, який почав 3 проведення серії антиамериканських реформ. Хоча Вашингтон і визнав новий кубинський уряд, відносини між двома 
країнами різко погіршилися. Білий дім, який прагнув повернути Кубу до сфери свого впливу, звернувся до загальновживаних у латиноамериканському регіоні методів політичного і економічного тиску: від торгових обмежень, різних диверсій i операцій з фізичного усунення Ф. Кастро до економічного ембарго і збройного вторгнення на Плая Хірон кубинських емігрантів, підготовлених ЦРУ. Однак, 3 огляду на зовсім іншу політичну ситуацію на Кубі, дії США виявилися неефективними. Крім того, наполегливість політики Вашингтону підштовхнула уряд Ф. Кастро звернутися за допомогою до СРСР. В результаті, конфлікт був перенесений з регіонального рівня на глобальний і набув характеру американськорадянського протистояння і привів до виникнення Кубинської ракетної кризи $1962 \mathrm{p}$.

Слід зазначити, що успіх революції на Кубі у 1959 р. і прорадянські настрої іiі політичного керівництва змусили Сполучені Штати переглянути свої підходи до країн Латинської Америки і повернути регіон в орбіту пріоритетних напрямків своєї зовнішньої політики. При цьому сама Куба, як форпост СРСР у Західній півкулі, вийшла з латиноамериканського контексту зовнішньої політики США. 3 початку 1960-х рр. вона стала займати одне з ключових місць серед американських національних інтересів і потребувала формування окремих зовнішньополітичних стратегій.

Таким чином, можна стверджувати, що у досліджуваний період політика США по відношенню до Куби і місце, яке вона займала серед зовнішньополітичних пріоритетів Вашингтону, зазнали певних змін. У ХІХ ст. у процесі становлення американської державності і під впливом політико-філософських ідей того часу, Куба розглядалася як потенційна складова частина самих Сполучених Штатів Америки, а основними методами, які застосовувалися до неї з боку США, були спроби викупу острова у Іспанії або можлива його анексія. Наприкінці XIX - на початку XX ст., через зміну політичної ситуації у Латинській Америці, Сполучені Штати були змушені відмовитися від намірів включити острів до свого складу. Основними методами їх політики відносно молодої республіки було застосування політичного і економічного впливу та, як результат, практично повний контроль над внутрішньою та зовнішньою політикою Куби, яка стала розглядатися з боку США вже у загальному контексті їх латиноамериканської політики.

Перемога Кубинської революції 1959 р. спричинила істотні зміни у зовнішньополітичному курсі США стосовно нового кубинського уряду, політика якого призвела до активного залучення СРСР до традиційно американської сфери впливу. Тим самим, з початку 1960-х рр. Куба вийшла 3 латиноамериканського контексту зовнішньої політики США i зайняла одне 3 ключових місць серед американських національних інтересів, але вже у вимірі американсько-радянського протистояння в рамках Холодної війни.

\section{Література}

1. Пасічник Н. С. Еволюція американської політики щодо Куби за президентства Дж. Кеннеді / Н. С. Пасічник // Гілея: науковий вісник. - 2014. - Вип. 82. - С. 443-447.

2. Скляренко О. О. Вплив кубинського лобі на зовнішню та внутрішню політику США (1960ті pp. - поч. XXI ст.) / О. О. Скляренко // Вісник Київського національного університету імені Тараса Шевченка. - 2012. - Вип. 109. - С. 55-57.

3. Тусинов Е. Г. Эволюция доктрины Монро в отношении Кубы / Е. Г. Тусинов // Известия Самарского научного центра Российской академии наук. - 2013. - Т. 15. - № 1. - С. 146-149. 
4. Agreement Between the United States and Cuba for the Lease of Lands for Coaling and Naval stations; February 23, 1903 / Lillian Goldman Law Library. Avalon Project: Documents in Law, History and Diplomacy. [Електронний pecypc]. http://avalon.law.yale.edu/20th_century/dip_cuba002.asp.

5. Caracas Declaration of Solidarity; March 28, 1954 / Lillian Goldman Law Library. Avalon Project: Documents in Law, History and Diplomacy. [Електронний ресурс] - Режим доступу: http://avalon.law.yale.edu/20th_century/intam10.asp\#1.

6. Franklin J. Cuba and the United States: A Chronological History / Franklin J. - N.-Y.: Ocean Press, 2008. $-420 \mathrm{p}$.

7. Imperialism and Expansionism in American History: A Social, Political, and Cultural Encyclopedia and Document Collection: in 4 vol. / ed.: C. J. Magoc, D. Bernstein. - Santa Barbara: ABCCLIO. 2015. - Vol. 1. - 1720 p.

8. LeoGrande W. M. Back Channel to Cuba: The Hidden History of Negotiations between Washington and Havana / William M. LeoGrande, Peter Kornbluh. - Chapel Hill: The University of North Carolina Press, 2015. -567 p.

9. List of the Public Acts and Resolutions Contained in This Volume. Acts of the Fifty-sixth Congress of the United States / Library of Congress. [Електронний ресурс]- Режим доступу: http://www.loc.gov/law/help/statutes-at-large/56th-congress/c56.pdf.

10. Monroe J. Seventh Annual Message. December 2, 1823 / J. Monroe. [Електронний ресурс] Режим доступу: http://www.presidency.ucsb.edu/ws/index.php?pid=29465.

11. Morales Dominguez E. United States - Cuban Relations: a critical history / E. Morales Dominguez, G. Prevost. - Plymouth: Rowman \& Littlefield Publishing Group, Inc., 2008. - 166 p.

12. Pérez L. A., Jr. Cuba and the United States: Ties of Singular Intimacy / L. A. Pérez, Jr. Athens: The University of Georgia Press, 2003. - 336 p.

13. Roosevelt F. D. 1 Inaugural Address. March 4, 1933 / F. D. Roosevelt. [Електронний ресурс]. - Режим доступу: http://www.presidency.ucsb.edu/ws/index.php?pid=14473.

14. Schlesinger A., Jr. The American Empire? Not So Fast / A. Schlesinger, Jr. // World Policy Journal. - 2005. - Vol. XXII. - № 1. - P. 43-46. [Електронний ресурс] - Режим доступу: http://web.archive.org/web/20080522110137/http:/www.worldpolicy.org/journal/articles/wpj05sp/schlesi nger.pdf.

15. The Statutes at Large of the United States of America from March, 1897, to March 1899, and Recent Treaties, Conventions, Executive Proclamations, and the Concurrent Resolutions of the Two Houses of Congress. Vol. XXX. - Washington: Government Printing Office, 1899. - 2026 p. [Електронний pecypc] / Library of Congress. [Електронний ресурс]. - Режим доступу: http://www.loc.gov/law/help/statutes-at-large/55th-congress/c55.pdf.

16. Treaty Between the United States of America and Cuba; May 29, 1934 / Lillian Goldman Law Library. Avalon Project: Documents in Law, History and Diplomacy. [Електронний ресурс]. - Режим доступу: http://avalon.law.yale.edu/20th_century/dip_cuba001.asp\#art2.

17. Treaty of Peace between the United States and Spain. Message from the President of the United States, transmitting a Treaty of Peace between the United States and Spain, Signed at the City of Paris, on December, 10, 1898. Accompanying Papers. Washington, Govt. print. off. 1899. - 692 p. / Library of Congress. [Електронний ресурс]. - Режим доступу: https://archive.org/details/treatyofpeacebet00spai.

18. White N. D. The Cuban Embargo Under International Law: El Bloqueo / N. D. White. - N.-Y.: Routledge, 2015. -208 p.

Надійшла до редколегії 04.09.2016

Ekaterina Kasatkina, Ph.D. student, Zaporizhzhya National University, Zaporizhzhya, Ukraine. CUBA'S PLACE AMONG THE U.S. FOREIGN POLICY INTERESTS (XIX - middle of the $X X$ centuries).

Abstract. This article deals with the role of Cuba in the U.S. foreign policy interests in the XIXmiddle of the XX centurie. The aim of the article is to characterize the general line of the U.S. foreign policy and to analyze its priorities. Particular attention is paid to the place of the Latin American region in the system of American national priorities. There were analyzed the factors which influenced on the formation of the U.S. policy towards Cuba and determined the nature of its qualitative changes in the given period. As a result of the research the author comes to the conclusion that the U.S. policy towards Cuba and its place among Washington's foreign policy priorities in XIX-middle of the XX centuries had 
been changing greatly throught its history. In the XIX century, when the U.S. had their state-building process, Cuba had been considered as a potential member of the United States of America. By the beginning of the XX century, Washington had refused the inclusion of Cuba as a member of the U.S. But the USA got almost complete control over domestic and foreign policy of the island. At the same time, Cuba was included in the general vector of the US Latin American policy. After the victory of the revolution in 1959 and the beginning of the Soviet-Cuban cooperation, the U.S. had regarded Cuba through the confrontation with the Soviet Union in the framework of the Cold War. Cuba had taken one of the top places among the U.S. national interests.

Key words: U.S., Cuba, Latin America, Big Stick Policy, Dollar Diplomacy.

УДК 327(73):327(729.1)

Наталія Пасічник, кандидат історичних наук, доцент, ВНЗ «Університет «Україна», Білоцерківський інститут економіки та управління

\section{ПОЛТТИКА США ЩОДО КУБИ ЗА ПРЕЗИДЕНТСТВА Б. ОБАМИ}

Анотація. У статті розглядається політика США щзодо Куби за президентства Б. Обами. 3'ясовано, щзо впродовж перших шести років політика адміністрації Б. Обами трунтувалася на збереженні економічних санкцій проти Куби за одночасного фінансування проектів, спрямованих на демократизачію кубинського суспільства, у тому числі спонсорування радіо- $i$ телевізійного мовлення. Водночас, починаючи з 2009 р. адміністрацією були інічійовані суттєві зрушення у політиці щзодо Куби, включаючи скасування деяких обмежень на грошові перекази і поӥздки на острів.

У статті підкреслюється, щзо якісні зрушення у американо-кубинських відносинах починаються за другої каденції Б. Обами. Новий курс щуодо Куби, анонсований президентом США, включав відновлення дипломатичних відносин з Кубою; перегляд визначення Куби як країни-спонсора міжнародного тероризму; збільшення подорожей, грошових переказів, торговельних та інформаційних потоків на Кубу та з острова. Автор досліджує фактори, які вплинули на зміну політичного курсу Вашингтону, зокрема неефективність політики ембарго; економічні переваги від нормалізації американокубинських відносин; вплив громадської думки; ставлення латиноамериканських країн до американо-кубинського протистояння; зміни, що відбуваються на Кубі зі вступом на посаду Р. Кастро в 2008 р. та інші чинники. У статті міститься оцінка поточного стану та перспектив процесу нормалізації американо-кубинських відносин.

Ключові слова: США, Куба, «кубинська відлига», ембарго, «Кубинська п'ятірка».

Протягом останнього року в американо-кубинських відносинах відбулися суттєві, навіть епохальні, зрушення, які вже у західних ЗМІ отримали назву «кубинська відлига». Адміністрація Б. Обами досягла вагомого прогресу у вирішенні понад п’ятдесятирічного конфлікту, тому аналіз американської політики щодо Куби й процесу нормалізації відносин між Вашингтоном і Гаваною $є$ актуальною дослідницькою проблемою.

Ще під час виборчої кампанії 2008 р. Б. Обама закликав до більшої взаємодії 3 Кубою та Латинською Америкою загалом, заявляючи, що тривала політика ізоляції виявилася неефективною у просуванні американських інтересів або допомозі людям, які постраждали за деспотичних урядів [13]. Кандидат у президенти обіцяв 